\title{
Revisiting currency swaps: hedging real estate investments in global city markets.
}

\begin{abstract}
Acknowledgments: We would like to gratefully acknowledge the support of Simon Mallinson (Real Capital Analytics), Dr. Nick Axford, Paul Lunn and Mary Suter (CBRE), who gave us access to their extensive databases.

Purpose: The purpose of this paper is to re-examine currency swaps as an effective hedging technique for individual asset performance in today's global real estate market, by considering hypothetical prime office investments across six different cities and five currency pairs. The perspective of a risk-averse, high net worth, non-institutional, smaller-scale Swiss investor is paired with investors from five additional national markets.
\end{abstract}

Design/methodology/approach: The study examines currency swaps in key office markets across three continents (Frankfurt, London, New York, Sydney, Warsaw and Zurich) and extends previous work on the topic by adopting both Monte Carlo (MC) and Latin Hypercube (LH) techniques to create stochastic samples for individual asset performance analyses. This is the first paper to apply LH sampling to currency swaps with underlying real estate assets, and the validity of this method is compared with that of MC. Four models are presented: 1) the experience of the domestic investor (no exchange rate fluctuations); 2) an unhedged direct foreign investment; 3 ) hedging rental income and initial purchase price via a currency swap; and 4) hedging rental income and anticipated terminal value.

Findings: The efficacy of a swap depends on the historical framework of the exchange rates. If the foreign currency depreciates against the domestic one, hedging the repatriated cashflow of a property investment proved superior to the unhedged strategy (EUR, GBP, PLN and USD to the CHF). An investor would benefit from exposure to an appreciating foreign currency (CHF to the EUR, GBP, PLN and USD), with an unhedged strategy clearly outperforming the currency swap as well as the domestic investor's performance, while a historically sideways fluctuating exchange rate (AUD to the CHF) also favours an unhedged approach. In all scenarios, unexpected economic or market shocks could cause negative consequences on the repatriated proceeds.

Practical limitations/implications: This research is of interest to small-scale, noninstitutional investors aiming to develop strategies for currency risk mitigation in international investments for individual assets; however, tax-optimising strategies and the implications on a larger portfolio have not been taken into account.

Originality/value: There is no recent academic work on the efficacy of currency swaps in today's global office market, nor has the position of smaller scale high net worth investors received much academic attention. This research revisits the discussion on their validity, providing contemporary insight into the performance of six markets using $\mathrm{LH}$ as an alternative and original sampling technique.

Keywords: Market uncertainty, Exchange rate risk, Currency swaps, Office markets, International investment, Global market.

Paper type: Research paper. 


\section{Introduction}

Recent decades have seen substantial capital flows into global real estate markets, through both foreign direct investment (FDI) and indirect real estate vehicles. Driven by diversification benefits (Wilson \& Zurbruegg, 2003; Markowitz, 1952) and chasing higher returns, international real estate investment has evolved in cycles, with country and city markets typically experiencing peaks followed by periods of stagnation (Barras, 2009). Irrespective of more recent discussions concerned with market convergence, diversification strategies between countries generally remain strategically viable (Srivatsa \& Lee, 2012); however, such viability depends on subjective investor appetites for risk, return and real estate vehicle choice. It is also dependent on the amount of capital available, and typically global institutions are able to more strategically diversify their investments, especially when compared with a smallerscale private investor. However, the potentially troublesome characteristics of FDI, such as lack of local knowledge, data availability and market transparency, combined with the illiquid, immobile characteristics of heterogeneous direct property often result in challenging investment conditions. Consequently, alternative and evolving real estate investment vehicles, such as securities (Lang \& Scholz, 2015; Hoesli \& Reka, 2013), indices (Stevenson, 2000), REITs (Moss et al., 2015), unlisted funds (Fuerst \& Matysiak, 2013) and currency swaps (Worzala et al., 1997; Ziobrowski et al., 1997), have been the subject of considerable academic discussion in relation to risk trends and return volatility, and the overarching question of how real estate could be successfully integrated into mixed-asset international portfolios.

One common hedging method is 'currency diversification'. Following Modern Portfolio Theory, diversifying currency exposure allows rising currencies to compensate for falling ones, and nets out in countries with correlated exchange rates (Odier \& Solnik, 1993; Worzala, 1995). However, for investors with only limited capital to deploy a currency diversification strategy via a large portfolio of properties might not be an option. Hedging individual investments, on the other hand, can be achieved through a wide spectrum of instruments, such as financial derivatives including futures, forwards, options and swaps. Originally designed for short to medium-term financial products like shares and bonds, derivatives can also be used for hedging the currency risk on real estate investments and a number of studies have explored their suitability (Johnson et al. 2001, 2005, 2006; Worzala et al. 1997; Ziobrowski \& Ziobrowski 1993). Despite some success, most of the products available face considerable drawbacks because of the long-held and illiquid nature of real estate (Baum \& Hartzell, 2012). Nevertheless, financial derivatives, including forward and future contracts, options and swaps, are powerful tools to hedge currency risk for specific investments.

Exchange rate shifts and fluctuations can also have a significant impact on risk mitigation, returns and diversification strategies related to investing in real estate (Newell \& Webb, 1996; Worzala, 1995). The purpose of this paper is to specifically examine the efficacy of currency swaps as a hedging technique in today's global real estate market for individual property investments. The research considers hypothetical prime/core office investments across six different cities and currency pairs. As there is no recent academic work on this topic and much of the research relating to currency swaps has not been further developed or reassessed following the GFC, this paper revisits the discussion on the validity and usefulness of currency swaps in the international market. In addition, contemporary insight is provided into the performance of six city markets, pairing Zurich (CHF) with Frankfurt (EUR), London (GBP), New York (USD), Sydney (AUD) and Warsaw (PLN). 
The perspective of a smaller-scale Swiss investor is adopted to examine the possible impact of the Swiss National Bank's abolition of the minimum exchange rate of 1.20 Swiss Franc (CHF) to the Euro (EUR) in January 2015. This monetary mechanism was introduced in September 2011 to counteract the overvaluation of the Franc in a period of uncertainty and fluctuation in the financial markets (SNB, 2015). The abolition of the minimum exchange rate saw the CHF's value rise substantially against the EUR and other currencies, effectively creating volatility across a broad range of global financial markets. Combining these factors with the current uncertainty in the financial and real estate markets relating to political shifts, such as the Brexit referendum and the American presidential election, this research is a timely and topical re-evaluation of international investment strategies to mediate exchange rate risk from the perspective of a risk averse, non-institutional investor. Although global flows are driven by institutional investors, private investors, albeit as a much smaller part of the market, are also actively growing and in such a diverse market these investors motivations and opportunities are often overlooked in academic literature. In the UK, for example, from 20052015 UK private investors share of the direct market grew by 19\% (PIA, 2016). RCA also report that private investors are net buyers in the US market (Costello, 2016), and smaller scale, yet high net worth investors may find that they can achieve higher returns (if not diversification benefits), by investing out of their domestic markets. Contemporary examples include outward investment into international real estate from smaller domestic markets, such as the Middle East, and these high net worth international investors have now become an indelible part of the global real estate market today. Switzerland also has a relatively limited domestic real estate market, and considering the financial uncertainty experienced there and in Europe, provides an interesting study for this research. In addition, the paper builds on previous work by Johnson et al. (2001; 2005; 2006) and Worzala et al. (1997), building on Monte Carlo (MC) simulation and developing this with the use of Latin Hypercube (LH) as an alternative and original sampling technique.

\section{Risks in international real estate investments}

Concomitant to the evolution of the increasingly interconnected global real estate market in recent decades, numerous studies have emerged demonstrating the diversification benefits of international real estate investment (Baum \& Hartzell, 2012; Hoesli et al., 2004; Eichholtz, 1996; Baum, 1995). The true motivation behind international real estate investment and diversification will differ between investors and their relevant strategies: approaches are subjective and contingent on both endogenous and exogenous market factors. Typically, the degree of benefit derived from diversifying to include international investments is contingent on the international market's correlation with an investor's domestic market, the equity and the bond markets (Sirmans \& Worzala, 2003; Lizieri \& Finlay, 1995). Harking back to Markowitz's (1952) mean variance criteria, an investor ideally wants to maximise returns, while minimising risk; however, capital flows outside of a domestic market incur additional risks that require mediation.

National regulations, capital controls, taxes, market maturity and local knowledge (Keogh \& D'Arcy, 1994) are also crucial factors in determining the target country for international real estate investment, and are typically accounted for when allocating assets in line with risk return expectations (Odier \& Solnik, 1993). Additional risks reflect political and economic uncertainty, market (il)liquidity, brokerage processes, cultural perspectives on real estate trading and volatile exchange rates. The risk associated with exchange rate movements disadvantages the international investor against the local counterpart, and subsequently increases uncertainty. Acquisition of an international property typically involves two steps. Cash in the domestic currency needs to be translated into the foreign one at the current exchange rate and subsequently, the foreign currency is used to buy the asset. A reversion of this procedure must take place upon sale of the property. As a result, the investor is exposed to volatility in 
the exchange rate, such that risk reduction and returns on foreign investments are dependent on the behaviour of currency movements (Soenen \& Lindvall, 1992). This phenomenon is widely recognised as 'currency risk' and can have a significant impact on returns, therefore increasing the risk of the investment (Eun \& Resnick, 1988; Sirmans \& Worzala, 2003).

Systematic movements in exchanges rates are associated with differentials in GDP, interest rates and inflation between countries (Worzala et al., 1997).In theory, exchange rates drive towards market equilibrium in prices and parity where no-arbitrage opportunities exist as they operate as 'market clearing prices that equilibrate supplies and demands in foreign exchange markets' (Hoesli and MacGregor, 2000: 250). Ziobrowski et al. (1997) demonstrated how currency risk remains a significant investment influence, even over extended time periods, where trends should theoretically reach equilibrium. This is supported by the 'Exchange-RateDisconnect-Puzzle', which implies a disconnection between economic elements and exchange rates (Cheung et al., 2005; Mark, 1995). As random walks in currency movements can be observed, and are connected to interest and inflation rates, anticipating future fluctuations and estimating the level of hedging necessary is problematic (Rossi, 2013; James et al., 2012), leading to increased uncertainty for an investor. Policy changes can also directly affect exchange rates and currency movements. The decision by the Swiss National Bank (SNB) to abolish the minimum exchange rate of the CHF to the EUR destabilised the Swiss financial market, led to devaluations of currency internationally and substantial increases in currency risk in Switzerland. This situation prompted the current exploration of a Swiss real estate investor's perspective, examining currency swaps as a risk hedging device.

\section{Currency swaps as tools for international real estate investors}

Insuring against disadvantageous outcomes, hedging can be implemented regardless of actualisation of perceived risks, or installed as a safety net. In the case of international investments, hedging methods to partially eliminate exposure to adverse currency movements can reduce the overall risk level of a portfolio and increase the global return equilibrium for investors (Dales \& Meese, 2001; Soenen \& Lindvall, 1992). At the same time, hedging can lead to a reduction in returns, primarily due to an increase in transaction costs for processing the hedge. An adverse side effect of protecting against exchange rate fluctuations is that any gains from positive movements are also, at least partially, hedged away (Odier \& Solnik, 1993).

Another consideration in hedging investment transactions is the proportion of total capital to protect. Dales and Meese (2001) recommend a partial hedge, where additional returns from unhedged capital can be retained. Considering that core direct real estate has characteristics of a secure investment like bonds, hedging at least a portion is advisable (Baum \& Hartzell, 2012). However, since most hedging instruments are designed for short-term horizon assets, many strategies are not suitable or too costly for real estate, traditionally held over a longer time period (Ball et al., 1998; Johnson et al., 2006; Worzala, 1995). The appropriate strategy, therefore, depends on the specific asset class, the available capital, the anticipated time frame of the investment and the investor's risk appetite.

As the real estate industry becomes increasingly globalized with a large number of crossborder transactions, hedging the currency risk by swapping exchange rates has emerged. Currency swaps are agreements between parties to exchange one currency with another, then reversing the currency exchange periodically sometime in the future, with the principal amount exchanged on redemption. Typically, a currency swap in the context of real estate consists of three elements; exchange of principal, cash flow (from FDI income in real estate), and reverse 
exchange of principal. However, swaps not only diminish the downside risk, but also lower the upside potential from currency fluctuations. Moreover, the transaction costs of the swap, which comprise of a setup fee and periodical costs on interest payments, lower the return (Worzala et al., 1997). The possibility of default of the counterparty, especially on the final principal exchange, elicits a considerable risk level on the agreement, despite the reduction of currency risk. Key in this case is finding a credit-worthy counterparty that is willing to engage in a swap agreement. This can be difficult in a real estate investment where exactly the same amount of money, the same cash flow pattern and the investment maturity date need to match (Ziobrowski et al., 1997).

When choosing a currency swap, the return strongly depends on the hedging scenario. A possible appreciation or depreciation of an investment is not protected when the initial purchase price is used as the principal amount for the swap (Johnson et al., 2005, 2006). However, if the terminal value is being swapped, there is a risk of over- or under-hedging since the anticipated sales proceeds at the end of the holding period are prone to uncertainty (Johnson et al., 2001). This makes results particularly sensitive to the assumptions used and will therefore be an influential element of this research.

Only a limited amount of literature exists that investigates hedging of currency risk in international real estate investments with currency swaps. Moreover, these studies are already over a decade old and have never touched the specific currency pairs examined in this work. Considering the recent fluctuations of the CHF, a gap in the literature is closed with the findings of this work. The analysis in the present case is based on the studies of Johnson et al. (2001, 2005, 2006), Worzala et al. (1997) and Ziobrowski et al. (1993; 1997), who used different forms and approaches to study currency swaps in the real estate industry. All studies demonstrated a reduction of risk and volatility, where the swap improves risk-adjusted returns and reduces the risk of negative net-present-values (NPVs), thus making currency swaps superior to other hedging instruments. Furthermore, Ziobrowski et al. (1997) found a reduced positive correlation amongst assets in a portfolio, which implies that hedging with currency swaps creates diversification benefits.

Johnson et al. (2005; 2006) compared an unhedged international office investment made by a US investor in the city of London with two scenarios: 1) a swap of the initial investment value and the periodic cash flows and 2) a swap of the cash flow and the anticipated terminal value at the end of the holding period. Both works showed that hedging the initial investment performs best for risk-adjusted returns, thus making it the optimal hedging option under the applied conditions. All analysed studies confirmed that hedging with a currency swap is superior to being exposed to unhedged exchange rate fluctuations from a risk-adjusted return perspective. Yet, this also depends on the risk appetite of the investor, since swaps costs reduce returns.

The controversy of using ex-post data to forecast real estate returns as well as currency exchange rates is an on-going discussion in the literature. Drawing on the fact that exchange rates adopt a random walk along a historical trend line, forecasting currency movements contains high uncertainty. Consequently, where research is using historical data for predictions about the future (e.g. Ziobrowski et al., 1997), it means that the investment decision is made in a prior, expectations context (Johnson et al., 2001). Since investors are not able to accurately forecast the future development of the investment, research would effectively deviate substantially from reality. Moreover, a single, unique span is being treated as representative for all possible outcomes when only ex post data is employed (Johnson et al., 2001). 


\section{Methodology and data}

\section{Monte Carlo (MC) and Latin Hypercube (LH) Simulations}

The methodological approach adopts MC and LH simulations to examine the success of using currency swaps in a forward-looking expectations framework for a five year holding period, beginning mid-2016. The hypothetical risk-averse Swiss investor is investing in five other global city markets: Frankfurt (EUR), London (GBP), New York (USD), Sydney (AUD) and Warsaw (PLN). The reverse scenario is also analysed, assessing the perspective of investors from each of these cities engaging in a currency swap with an underlying property in Zurich. These cities were chosen to provide a range of currencies for comparison across a variety of geographical locations, while also offering strongly performing and well-established commercial real estate markets. In addition, as mature, potentially converging global markets, these cities may respond in similar ways, therefore negating diversification benefits associated with currency hedging. Warsaw is included to offer insight into an emerging market and to assess the potential for adding value through risk adjusted returns.

Conceptually and methodologically, there were a number of reasons for adopting this approach for a small-scale, high net worth investor, looking to purchase assets directly in nondomestic markets. As aforementioned, investors want to maximise returns while minimising risks and models regarding asset allocation and pricing have been created for the stock market, then further adopted in the real estate market. However, in applying the mean variance criteria through modern portfolio theory (MPT), or indeed through a capital asset pricing model (CAPM) approach, larger data samples are required to account for the risk and return characteristics of a collection of assets, rather than individual assets. Therefore these data heavy models would be more appropriate for performance analyses of institutional, multiasset portfolios, which are also able to adopt techniques which provide currency overlays to their overall exchange rate exposure and more sophisticated consideration of interest rate parity. A small-scale, high net worth investor is not able to meet such criteria. Although institutional portfolios are more diversified, Falkenbach (2009) finds that for international investors, expected return and the economy of the non-domestic market are more important than perceived diversification benefits when selecting markets for investment. The technique adopted here reflects a variety of markets with varied economies, currencies and expected returns, due to the investor's hypothetical investment approach. The conceptual methodology also builds on previous work by Brown (2004), whose work examined private investors' motivations and return profiles. These investors sit within what is defined as 'tier two'; noninstitutional investors owning between 4-100 real estate assets (with residential investors occupying tier one and institutional investors tier three). Brown reflects on the importance of tier two investors in the real estate market and suggests that 'simulation is perhaps the only practical way to implement portfolio analysis at the individual level' (2004: 113). Through MC and LH simulation, a more granular analysis of currency swaps applied to individual property is achieved in this research.

The method employs randomly sampled input variables, adopting stochastic simulations to explore the hedging capacity of currency swaps for real estate investors using MC and LH. This differs from the retrospective approach used by Ziobrowski et al. (1997) and is developed from previous studies by Johnson et al. $(2001 ; 2005 ; 2006)$ and Worzala et al. (1997), which used MC to explore currency risk hedging. Each, MC and LH model systems where outputs are directly affected by the randomness of the input variables (Brandimarte, 2014; Sokolowski, 2010).

An MC simulation randomly samples defined variables across an input distribution, generating a multitude of pseudo-random ${ }^{1}$ iterations aggregated into a final result (Sayce et al., 2006). In addition to the aforementioned research by Johnson et al. $(2001 ; 2005 ; 2006)$ and Worzala et 
al. (1997), Hoesli et al. (2010) applied MC in combination with discounted cash flow analysis to account for randomness in Swiss property valuations. Other related studies using $\mathrm{MC}$ by Amedee-Manesme et al. (2013) and Hoesli et al. (2006) focused on pricing real estate portfolios. However, LH as a modelling technique has only once been applied in the context of real estate analysis by Pfnür \& Armonat (2013), who examined uncertainty in modelling operational cash flows for assets. LH, introduced by McKay et al. (1979), extends on MC techniques and, unlike MC, employs stratified sampling. Thus, all input dimensions are simultaneously stratified by splitting the probability distribution into vertical slices, where the sampled numbers are generated systematically in the course of the simulation (Sayce et al., 2006; Loh, 1996). LH provides a more evenly distributed, fully stratified randomised sampling method (Steinberg \& Lin, 2006), therefore applying both MC and LH approaches offers a novel methodology for comparison.

\section{Swap scenarios \& data}

Two scenarios have been investigated - the perspective of a Swiss investor in each of the examined foreign markets (scenario A) and the reverse scenario (scenario B). For each scenario, four investment strategy models were compared:

Model 1) the experience of the domestic investor (no exchange rate fluctuations);

Model 2) an unhedged foreign direct investment;

Model 3) hedging rental income and initial purchase price via a currency swap;

Model 4) hedging rental income and anticipated terminal value (TV) via a currency swap.

Model 4 allows for anticipated capital value appreciation or depreciation, yet it is prone to greater uncertainty as it requires a forecast of sales price, rental growth and exit cap rate to determine the anticipated TV.

Within the four models simulated, exchange rate fluctuations, rental growth and exit cap rates were set as random variables and created as stochastic values using $\mathrm{MC}$ and $\mathrm{LH}$. Considering trends in historic exchange rate movements as well as historic capitalisation rates, only the changes in these variables were randomised, creating a more realistic representation of market trends. The different net present values (NPVs) of the hypothetical office assets in each city constitute the performance of the investment, therefore the NPV was the simulation output. All model inputs can be observed in Table 2.

\section{Exchange rates}

As the Euro was introduced in 1999, analysis of the currencies begins at this date, with data obtained from the SNB from Jan/1999 to Jun/2016. Quarterly means were calculated, resulting in 70 observations. The standard deviation (SD) was calculated quarter by quarter and across the five year holding period, i.e. lagged by 20 quarters. Increased SD in exchange rates was observed per quarter, therefore volatility from quarter to quarter and across the five year holding period was randomised for the simulation, accounting for increased risk as the holding period increases.

Johnson et al. (2005) highlighted a potential relationship between currency, inflation and economic performance that needs to be accounted for when simulating exchange rate movements. The authors argue that due to the heterogeneous, immobile nature of direct real estate and the absence of a central market, the industry is seen as a non-traded sector. This implies a weak correlation between exchange rate movements and real estate returns. Johnson et al. (2005) examined the relationship between the studied inputs and found no 
statistically significant relationship between the GBP/USD exchange rate, the 5-year rental growth rate and the cap rate for their hypothetical asset.

Table 1 depicts correlation coefficients that have been calculated for the currency pairs in this work. Fluctuating below 0.5 and above -0.5 , respectively, these values show no statistically strong correlation between the randomised inputs.

Considering a 5-year holding period for the assets, a sub-period correlation test was carried out. Slightly stronger correlations were identifiable when looking at rolling 5-year periods, however, the coefficients were on average still within the acceptable range of $0.5 /-0.5$, where no strong correlation can be ascertained. Considering that a trend in the data was at least to a certain degree identifiable, a correlation between the variables may also indicate spurious regression (Brooks \& Tsolacos, 2010). Therefore, the absence of a statistically significant relationship, as identified by Johnson et al. (2005), could be confirmed as consistent for the examined exchange rates and office markets in this study.

Table 1: Correlation coefficients of input variables

\begin{tabular}{|l|c|c|c|}
\cline { 2 - 3 } \multicolumn{1}{c|}{} & \multicolumn{3}{c|}{ Correlation Coefficients } \\
\cline { 2 - 3 } \multicolumn{1}{c|}{} & $\begin{array}{c}\text { Exchange Rate } \\
\text { Change/Cap Rate }\end{array}$ & $\begin{array}{c}\text { Exchange Rate Change/ } \\
\text { Rental Growth Rate }\end{array}$ & $\begin{array}{c}\text { Cap Rate/ } \\
\text { Rental Growth Rate }\end{array}$ \\
\hline Swiss investor - Scenario A & 0.20875 & 0.02995 \\
\hline Frankfurt & 0.17477 & 0.29757 & -0.42913 \\
\hline London & -0.15395 & -0.12368 & 0.36963 \\
\hline New York City & -0.12285 & -0.32882 & 0.13322 \\
\hline Sydney & -0.15868 & 0.32138 & 0.18008 \\
\hline Warsaw & 0.20344 & -0.01870 & \multirow{2}{*}{0.04479} \\
\hline Reverse scenario & - investment in Zurich - Scenario B \\
\hline German & -0.17192 & -0.09879 & \\
\hline British & -0.22896 & 0.05449 & \\
\hline US-American & 0.19469 & -0.04708 & \\
\hline Australian & -0.16476 & -0.15151 & \\
\hline Polish investor & -0.39987 & &
\end{tabular}

\section{Property data}

Assuming a forward looking expectations framework, the acquisition date of the assets is 01/07/2016, with a 5 year holding period. For the purpose of the swap, assets were assumed to be newly built, prime office buildings of identical size.

The work incorporates two different rent review systems into the simulations - alignment to the Consumer Price Index (CPI) and market rent reviews. Corresponding to market practice, Germany and Switzerland indexed rents are annually adjusted in line with CPI. The typical UK lease structure of five yearly reviews is linked to the holding period length, and the same structure is adopted for the New York market, while for Sydney and Warsaw annual adjustments to market rental growth have been assumed. The variety of review approaches, which affect the rental income, allows for additional insights into the efficacy of the currency swaps on property cash flows.

For the hypothetical office assets, the modelled market rents were set using quarterly rent series from Q1/2000 to Q2/2016 for Frankfurt, London, New York, Sydney, Warsaw and Zurich, provided by CBRE. Historical office cap rates, provided by RCA, from Q1/2007 to Q2/2016 of CEE region (Warsaw), German A-cities (Frankfurt), London, New York, Sydney and Zurich, were used to set the initial cap rates for the model. The cash flow in the model 
was discounted using the interest rate of a Swiss gilt (issued on 11.03 .2015 at $1.25 \%$;ISIN: $\mathrm{CH} 0224397130)$, corresponding to the view of a Swiss investor. No risk premium was added due to the potential for distorting results as premiums vary between investors (in line with Johnson, 2005). However, this could be included in further research. As the research considered hedged versus unhedged scenarios, it excluded transfer and operational taxes, and did not consider tax-optimising structures. Finally, management fees were set at $5 \%$.

\section{Swap rates}

Since currency swaps are an OTC product, rates will vary depending on the contract and the facilitator. The costs for setting up the swap as well as the periodical costs on the quarterly cash flow were set by ranking the currency pairs according to the respective SD of the quarterly exchange rate as a measure for volatility. Starting with origination fees at $1 \%$ and periodical costs at $0.1 \%$ for the exchange rate with the lowest SD, steps of $10 \mathrm{bps}$ for set up costs and 5bps for quarterly costs were assumed. Considering that the risk for the swap counterparty increases with higher volatility of the exchange rate, this assumption seems realistic.

Table 2: Summary of simulation inputs

\begin{tabular}{|c|c|c|c|c|c|}
\hline & \multicolumn{5}{|c|}{ Scenario A } \\
\hline & Frankfurt & London & New York & Sydney & Warsaw \\
\hline $\mathrm{GLA}\left(\mathrm{m}^{2}\right)$ & \multicolumn{5}{|c|}{10,000} \\
\hline $\mathrm{GLA}\left(\mathrm{ft}^{2}\right)$ & \multicolumn{5}{|c|}{107,639} \\
\hline Rent / m² p.a. & $€ 474.00$ & $£ 1291.67$ & $\$ 814.50$ & 1126.00 AUD & 1100.39 PLN \\
\hline Management costs & \multicolumn{5}{|c|}{$5.00 \%$} \\
\hline Acquisition date & \multicolumn{5}{|c|}{01.07 .2016} \\
\hline Disposal date & \multicolumn{5}{|c|}{30.06 .2021} \\
\hline Initial cap rate & $5.93 \%$ & $4.44 \%$ & $5.75 \%$ & $5.1 \%$ & $6.29 \%$ \\
\hline $\begin{array}{l}\text { Net initial purchase } \\
\text { price }\end{array}$ & $€ 75,935,919$ & $£ 276,370,405$ & $\$ 134,570,278$ & $\begin{array}{l}209,745,098 \\
\text { AUD }\end{array}$ & $166,195,957$ PLN \\
\hline Discount Rate & \multicolumn{5}{|c|}{$1.25 \%$} \\
\hline Swap origination fee & $1.50 \%$ & $1.80 \%$ & $1.80 \%$ & $1.70 \%$ & $1.00 \%$ \\
\hline $\begin{array}{l}\text { Swap periodical } \\
\text { costs }\end{array}$ & $0.35 \%$ & $0.50 \%$ & $0.40 \%$ & $0.45 \%$ & $0.10 \%$ \\
\hline Initial exchange rate & 1.096 & 1.393 & 0.970 & 0.724 & 0.251 \\
\hline $\begin{array}{l}\text { Quarterly exchange } \\
\text { rate change }\end{array}$ & $\begin{array}{c}\text { Mean }-0.73 \% / \\
\text { SD } 3.08 \%\end{array}$ & $-1.49 \% / 6.57 \%$ & $-0.64 \% / 4.70 \%$ & $-0.23 \% / 4.07 \%$ & $-0.18 \% / 1.88 \%$ \\
\hline $\begin{array}{l}\text { Exchange rate } \\
\text { change at end of } \\
\text { holding period }\end{array}$ & $\begin{array}{c}\text { Mean }-14.19 \% / \\
\text { SD } 19.18 \%\end{array}$ & $-36.44 \% / 31.74 \%$ & $-24.10 \% / 14.91 \%$ & $2.74 \% / 11.06 \%$ & $-4.10 \% / 7.57 \%$ \\
\hline Exit cap rate & $\begin{array}{c}\text { Mean } 5.75 \% / \\
\text { SD } 1.75 \% \\
\end{array}$ & $5.69 \% / 0.82 \%$ & $5.58 \% / 1.45 \%$ & $7.3 \% / 1.99 \%$ & $7.03 \% / 2.36 \%$ \\
\hline Rental growth rate & $\begin{array}{c}\text { CPI Mean } \\
1.44 \% / \text { SD } \\
0.76 \% \\
\end{array}$ & $\begin{array}{c}@ 20 \text { quarter } \\
20.68 \% / 29.45 \%\end{array}$ & $\begin{array}{c}@ 20 \text { quarter } 12.03 \% \\
/ 20.83 \%\end{array}$ & $\begin{array}{c}\text { annual } 2.70 \% / \\
1.03 \%\end{array}$ & $\begin{array}{c}\text { annual } 0.71 \% / \\
15.68 \%\end{array}$ \\
\hline
\end{tabular}

\begin{tabular}{|l|c|c|c|c|c|}
\cline { 2 - 6 } \multicolumn{1}{c|}{} & \multicolumn{5}{c|}{ Scenario B } \\
\cline { 2 - 5 } \multicolumn{1}{c|}{} & EUR & GBP & USD & AUD & PLN \\
\hline GLA $\left(\mathrm{m}^{2}\right)$ & \multicolumn{5}{c|}{} \\
\hline
\end{tabular}




\begin{tabular}{|c|c|c|c|c|c|}
\hline $\mathrm{GLA}\left(\mathrm{ft}^{2}\right)$ & \multicolumn{5}{|c|}{107,639} \\
\hline Rent / m² p.a. & \multicolumn{5}{|c|}{$800.00 \mathrm{CHF}$} \\
\hline Management costs & \multicolumn{5}{|c|}{$5,00 \%$} \\
\hline Acquisition date & \multicolumn{5}{|c|}{01.07 .2016} \\
\hline Disposal date & \multicolumn{5}{|c|}{30.06 .2021} \\
\hline Initial cap rate & \multicolumn{5}{|c|}{$4.60 \%$} \\
\hline $\begin{array}{l}\text { Net initial purchase } \\
\text { price }\end{array}$ & \multicolumn{5}{|c|}{$165,217,391 \mathrm{CHF}$} \\
\hline Discount rate & \multicolumn{5}{|c|}{$1.25 \%$} \\
\hline Swap origination fee & $1.10 \%$ & $1.20 \%$ & $1.30 \%$ & $1.40 \%$ & $1.90 \%$ \\
\hline $\begin{array}{l}\text { Swap periodical } \\
\text { costs }\end{array}$ & $0.15 \%$ & $0.20 \%$ & $0.25 \%$ & $0.30 \%$ & $0.55 \%$ \\
\hline Initial exchange rate & 0.9122 & 0.7179 & 1.0305 & 1.3814 & 3.9872 \\
\hline $\begin{array}{l}\text { Quarterly exchange } \\
\text { rate change }\end{array}$ & $0.42 \% / 1.88 \%$ & $0.42 \% / 1.95 \%$ & $0.46 \% / 3.46 \%$ & $0.40 \% / 5.32 \%$ & $1.94 \% / 13.48 \%$ \\
\hline $\begin{array}{l}\text { Exchange rate } \\
\text { change at end of } \\
\text { holding period }\end{array}$ & $8.02 \% / 10.06 \%$ & $10.6 \% / 9.38 \%$ & $16.3 \% / 10.36 \%$ & $3.72 \% / 14.86 \%$ & $38.96 \% / 58.67 \%$ \\
\hline Exit cap. rate & \multicolumn{5}{|c|}{$3.55 \% / 2.29 \%$} \\
\hline Rental growth rate & \multicolumn{5}{|c|}{ CPI $0.86 \% / 1.15 \%$} \\
\hline
\end{tabular}

\section{Simulation settings and model compositions}

The simulation for all four models for each asset was conducted simultaneously using the same sampling values in order to eliminate unnecessary noise, meaning that all cash flow inputs are the same for the models for each asset and iteration. This allows for a better comparison of the NPVs, as the differentials can be attributed only to the hedging method.

The MC and LH sampling was carried out using @Risk, a risk analysis add-in to Microsoft Excel. Mersenne Twister, a uniform pseudo-random number generator algorithm, generated the samples. As a variation of the 'twisted generalised feedback register' (TGFSR), the form of recurrence is superior to other generators (Matsumoto \& Nishimura, 1998). At the beginning of the simulation, random seeds were set so that every run had slightly different results and randomised inputs. The probability distributions of these sampled values were constructed using the @Risk 'distribution-fitting-tool', to calculate the best fits for the continuous input variables. The simulations ran with 100,000 iterations in total.

\section{Modelling methodology used for each of the four hedging scenarios}

The models used in the work were derived from Johnson et al. (2005). A discounted cash flow analysis was performed simultaneously to provide a better understanding of the influence of various model inputs over the 5 -year holding period. The exchange rate $\left(\widetilde{E R}_{t}\right)$, rental growth rates $(\widetilde{r g})$ and capitalization rates $(\tilde{c})$ were set as random variables in the $\mathrm{LH}$ and $\mathrm{MC}$ sampling, meaning that these rates fluctuated for every iteration according to the mean and SD. All random variables in the models are marked with a tilde $(\sim)$ above the respective variable.

Model 1 - No exchange rate fluctuations

$$
N P V_{\text {Domestic }}=\sum_{t=0}^{19} \frac{N O I N S_{t}}{(1+r)^{t}}+\frac{\widetilde{T V}_{20}}{(1+r)^{20}}-P_{0}
$$


Where:

$N P V_{\text {Domestic }}=\quad$ Net present value (NPV) of the investment for a domestic investor

NOINS $_{t}=$ Quarterly net operating income (not swapped) in period $\mathrm{t}$

$\widetilde{T V}_{20} \quad=\quad$ Terminal value (TV) of the asset

$P_{0} \quad=\quad$ Initial purchase price in foreign currency

$r \quad=\quad$ Quarterly 'risk-free' interest rate for Swiss gilts

$$
\widetilde{T V}_{20}=\frac{N \operatorname{NINS}_{0}(1+\widetilde{r g})}{\tilde{c}}
$$

Where:

$\begin{array}{lll}\text { NOINS }_{0} & = & \text { Not swapped net operating income in period } 0 \\ \widetilde{r g} & = & \text { Five-year rental growth rate } \\ \tilde{c} & = & \text { Exit capitalisation rate }\end{array}$

Model 2 - No hedging for currency risk

$$
N P V_{C H F}=\sum_{t=0}^{19} \frac{N O I N S_{t} \times \widetilde{E R}_{t}}{(1+r)^{t}}+\frac{\widetilde{T V}_{20} \times \widetilde{E R}_{20}}{(1+r)^{20}}-P_{0} \times E R_{0}
$$

Where:

$\begin{array}{lll}N P V_{C H F} & = & \text { NPV for a Swiss investor } \\ \widetilde{E R}_{t} & = & \text { Foreign exchange rate in period } \mathrm{t} \\ \widetilde{E R}_{20} & = & \text { Foreign exchange rate at period } 20 \\ \widetilde{E R}_{0} & = & \text { Foreign exchange rate at period } 0\end{array}$

Model 3 - Initial purchase price and rental income are hedged

$$
N P V_{\text {swapCHF }}=\sum_{t=0}^{19} \frac{\left(N O I S_{t} \times E R_{0}\right)_{t}}{(1+r)^{t}}+\frac{P_{0} \times E R_{0}+\left(\widetilde{T V}_{20}-P_{0}\right) \times E R_{20}}{(1+r)^{20}}-\left(P_{0} \times E R_{0}\right)-S C_{0}
$$

Where:

$N P V_{\text {SwapCHF }}=\quad$ NPV with a currency swap

NOIS $_{t} \quad=\quad$ Quarterly net operating income net of swap costs in period $\mathrm{t}$

$\left(\widetilde{T V}_{20}-P_{0}\right)=$ Change in value of the property in foreign currency

$S C_{0} \quad=\quad$ Origination costs for the currency swap

Model 4 - Expected TV and rental income are hedged

$$
\begin{aligned}
N P V_{\text {SwapTV }}= & \sum_{t=0}^{19} \frac{\left(N O I S_{t} \times E R_{0}\right)_{t}}{(1+r)^{t}}+\frac{\overline{T V}_{20} \times E R_{0}+\left(\widetilde{T V}_{20}-\overline{T V}_{20}\right) \times E R_{20}}{(1+r)^{20}} \ldots \\
& -\left(\overline{T V}_{20} \times E R_{0}\right)+\left(\overline{T V}_{20}-P_{0}\right) * E R_{0}-S C_{0}
\end{aligned}
$$

Where:

$\begin{array}{lll}N P V_{\text {SwapTV }} & = & \text { NPV with currency swap based on expected TV } \\ N O I S_{t} & = & \text { Quarterly net operating income net of swap costs in period } \mathrm{t} \\ \left(\overline{T V}_{20} \times E R_{0}\right) & = & \text { Principle swap amount based on expected TV }\end{array}$ 
$\begin{array}{ll}E R_{0} & = \\ T_{20} & = \\ S C_{0} & = \\ \left(\overline{T V}_{20}-P_{0}\right) * E R_{0} & = \\ \left(\widetilde{T V}_{20}-\overline{T V}_{20}\right) \times E R_{20} & =\end{array}$

Exchange rate in swap contract calculated net of cost Expected TV in period 20 Origination cost for the currency swap (based on $\overline{T V}_{20}$ ) Portion of the swap not spent on the initial investment Net gain/loss on sale after swap contract settlement

$$
\overline{T V}_{20}=\frac{\operatorname{NOINS}_{0}\left(1+\mu_{r g}\right)}{\mu_{\mathrm{c}}}
$$

Where:

$\begin{array}{lll}\mu_{r g} & = & \text { Mean five-year rental growth rate } \\ \mu_{\mathrm{c}} & = & \text { Mean exit cap rate }\end{array}$

\section{Results}

The models were used to examine whether hedging the exchange rate risk in an office building investment in Frankfurt, London, New York, Sydney and Warsaw is superior to an unhedged strategy from the perspective of a Swiss investor (scenario A). Additionally, the reverse scenario (scenario $B$ ) was examined, where investors quarterly repatriate the cash-flow from a Zurich office building into the EUR, GBP, USD, AUD and PLN, respectively. In order to judge the success of a currency swap, the median NPV and the coefficient of variation (CV; derived from mean NPVs and SD) were used. The former represents the results from a returns perspective, whereas CV is an indicator of dispersion and therefore the involved uncertainty. Hence, these outputs link an investor's two main concerns - return and risk. A lower CV suggests a less risky investment; however, this also incorporates upside-risk, which is typically less important to investors than downside-risk (Swisher \& Kasten, 2005). Simulation outcomes of all models are in $\mathrm{CHF}^{2}$, as conversions of the foreign currency was incorporated into the simulation for Scenario B.

Table 3 and Figure 1 show the simulation results for scenario A, using LH and MC sampling. In all cases a Swiss investor (model 2a) would see lower median returns than the respective domestic economic actor (model 1a) if all proceeds are repatriated into the CHF. The outcomes indicate that hedging with a currency swap (models $3 a$ \& 4a) creates higher median returns for less volatility in the Frankfurt, London, New York and Warsaw assets for a Swiss investor, compared to the unhedged model 2a, which showed the lowest NPV with the highest $\mathrm{CV}$. From these results it is apparent that the downside as well as the upside-risk is greater when no hedging strategy is employed, corresponding to a potentially unfavourable risk/return trade-off. In the case of London, an investment would result in a negative NPV if no currency swap is employed, resulting in losses due to full currency exposure to the GBP. This outcome is likely due to large depreciation of the GBP against the CHF over the last years, and the high standard deviations of quarterly lags for this currency pair. With respect to the hedging models, there is ambiguity whether hedging the initial purchase price and the rental income (model 3a) is superior to protecting the anticipated TV as well as the rental income (model 4a). For the Frankfurt and New York property, the gap between initial cap rate employed and the mean ECR stipulated from the series was below 20bps, whereas for the other assets the gap was above 1ppt, which is significantly larger (see table 2 above). Therefore, it seems that the preferred hedging strategy with currency swaps may depend on the current property market situation. If market cap rates are closer to the historical mean, such as for Frankfurt and New York, hedging the TV seems to be the superior method. On the other hand, if the economic 
environment leads to cap rates that are strongly divergent from the historical mean, as for the other assets, the preferred approach would be to hedge the initial purchase price.

Table 3: Scenario A - Median of NPVs (in CHF) and CV (LH \& MC);

\begin{tabular}{|c|c|c|c|c|c|c|c|c|c|c|}
\hline & \multicolumn{10}{|c|}{ Scenario A } \\
\hline & \multicolumn{2}{|c|}{ Frankfurt } & \multicolumn{2}{|c|}{ London } & \multicolumn{2}{|c|}{ New York } & \multicolumn{2}{|c|}{ Sydney } & \multicolumn{2}{|c|}{ Warsaw } \\
\hline & $L H$ & $M C$ & $L H$ & $M C$ & $L H$ & $M C$ & $L H$ & $M C$ & $L H$ & $M C$ \\
\hline $\begin{array}{l}\text { Median } \\
\text { NPV }\end{array}$ & $41.4 \mathrm{Mn}$ & $41.5 \mathrm{Mn}$ & $48.8 \mathrm{Mn}$ & $48.6 \mathrm{Mn}$ & $47.8 \mathrm{Mn}$ & $47.7 \mathrm{Mn}$ & $29.6 \mathrm{Mn}$ & $29.5 \mathrm{Mn}$ & $12.2 \mathrm{Mn}$ & $12.1 \mathrm{Mn}$ \\
\hline $\mathrm{CV}$ & 26.26 & 11.00 & 197.88 & 124.15 & 35.26 & 44.06 & 92.79 & 55.56 & 107.87 & -3552.46 \\
\hline $\begin{array}{l}\text { Median } \\
\text { NPV }\end{array}$ & $22.0 \mathrm{Mn}$ & $22.0 \mathrm{Mn}$ & $-63.7 \mathrm{Mn}$ & $-63.6 \mathrm{Mn}$ & $08.7 \mathrm{Mn}$ & $08.3 \mathrm{Mn}$ & $20.4 \mathrm{Mn}$ & $20.8 \mathrm{Mn}$ & $00.1 \mathrm{Mn}$ & $00.2 \mathrm{Mn}$ \\
\hline $\mathrm{cV}$ & 42.47 & 13.93 & -126.90 & 412.62 & 68.79 & 114.11 & 99.68 & 63.10 & 191.23 & -1089.33 \\
\hline $\begin{array}{l}\text { Median } \\
\text { NPV }\end{array}$ & $32.4 \mathrm{Mn}$ & $32.5 \mathrm{Mn}$ & $39.8 \mathrm{Mn}$ & $39.2 \mathrm{Mn}$ & $33.2 \mathrm{Mn}$ & $33.1 \mathrm{Mn}$ & 19.2 Mn & $19.1 \mathrm{Mn}$ & $08.7 \mathrm{Mn}$ & $08.7 \mathrm{Mn}$ \\
\hline $\mathrm{CV}$ & 30.27 & 10.22 & 122.11 & 204.79 & 32.67 & 51.81 & 109.73 & 67.17 & 165.23 & -1873.50 \\
\hline $\begin{array}{l}\text { Median } \\
\text { NPV }\end{array}$ & $32.6 \mathrm{Mn}$ & $32.7 \mathrm{Mn}$ & $29.9 \mathrm{Mn}$ & $29.7 \mathrm{Mn}$ & $40.0 \mathrm{Mn}$ & $39.9 \mathrm{Mn}$ & $18.3 \mathrm{Mn}$ & $18.2 \mathrm{Mn}$ & $07.5 \mathrm{Mn}$ & $07.4 \mathrm{Mn}$ \\
\hline $\mathrm{CV}$ & 30.15 & 10.18 & 133.16 & 210.62 & 29.42 & 46.78 & 110.99 & 67.62 & 166.58 & -1795.37 \\
\hline
\end{tabular}

Figure 1: Scenario A (LH), Comparison of Median NPVs

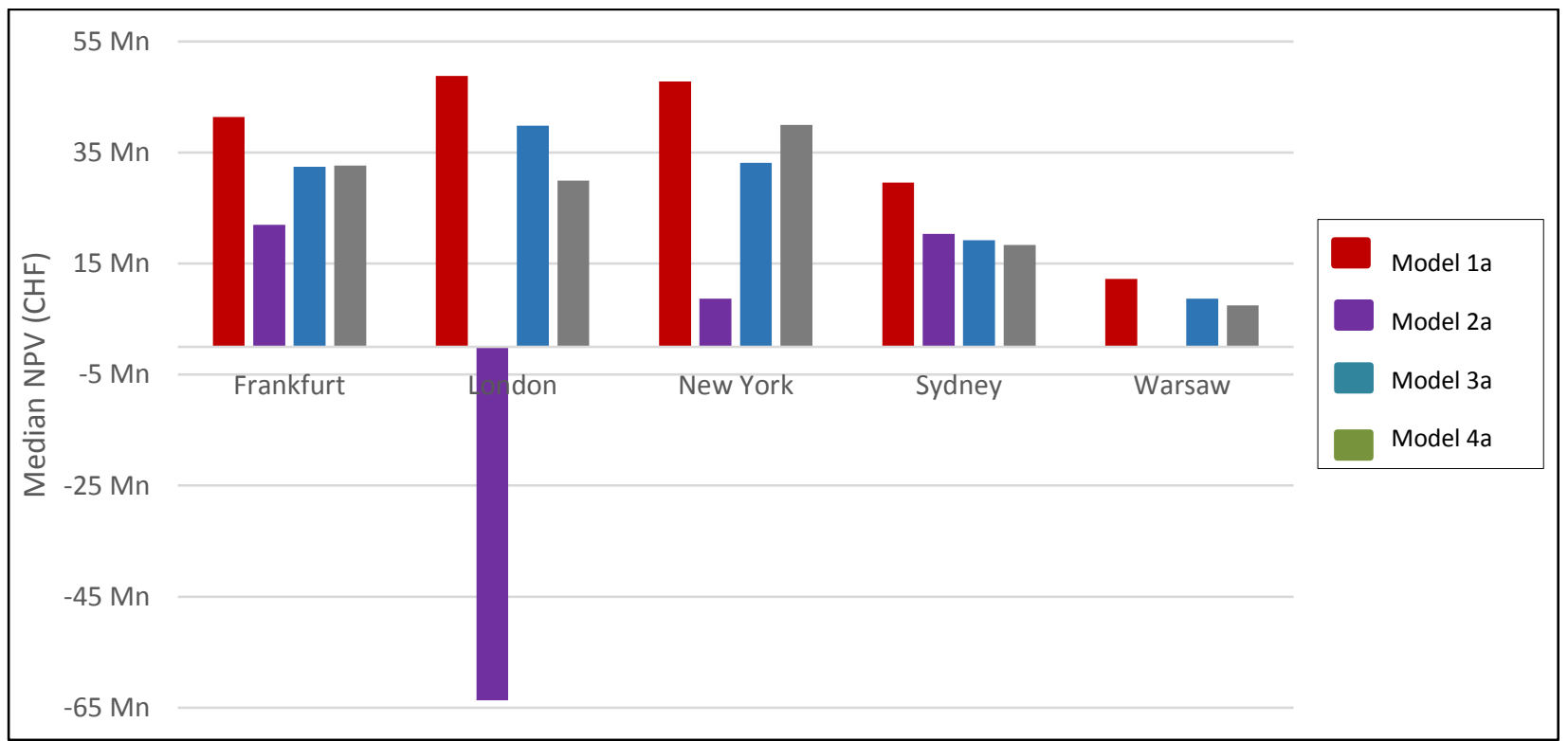

In contrast to all other markets examined, the investment in Sydney did not benefit from a currency swap. For the Australian asset, hedging the currency risk resulted in $6 \%$ and $10 \%$ lower returns in model $3 a$ and model $4 a$, respectively, compared to the swap-free strategy. Unlike the EUR, GBP, USD and, to most extents, the PLN, which all experienced a trend of constant depreciation, the exchange rate movements of the AUD fluctuated sideways against the CHF. Considering the slightly higher median NPV of the no-hedge strategy for the Sydney asset compared to the hedging approach as well as the $10 \%$ lower CV, full exposure to currency movements seems to be beneficial in this case. Therefore, the results indicate that hedging currency movements with a sideway trend could be counterproductive. 
In order to analyse the impact of currency swaps on returns and risk in more depth, the reverse scenario (scenario B) was conducted, where the cash flow from an investment in Zurich is repatriated quarterly into EUR, GBP, USD, AUD and PLN.

Table 4: Scenario B - Median NPVs (in CHF) and CV (LH \& MC)

\begin{tabular}{|c|c|c|c|c|c|c|c|c|c|c|c|}
\hline & & \multicolumn{10}{|c|}{ Scenario B } \\
\hline & & \multicolumn{2}{|c|}{ EUR } & \multicolumn{2}{|c|}{ GBP } & \multicolumn{2}{|c|}{ USD } & \multicolumn{2}{|c|}{ AUD } & \multicolumn{2}{|c|}{ PLN } \\
\hline & & $L H$ & $M C$ & $L H$ & $M C$ & $L H$ & $M C$ & $L H$ & $M C$ & $L H$ & $M C$ \\
\hline \multirow{2}{*}{$\begin{array}{c}\text { Model } \\
1 \mathrm{~b}\end{array}$} & $\begin{array}{l}\text { Median } \\
\text { NPV }\end{array}$ & $93.6 \mathrm{Mn}$ & $94.2 \mathrm{Mn}$ & $93.5 \mathrm{Mn}$ & $94.5 \mathrm{Mn}$ & $93.5 \mathrm{Mn}$ & $93.4 \mathrm{Mn}$ & $93.5 \mathrm{Mn}$ & $94.0 \mathrm{Mn}$ & $93.6 \mathrm{Mn}$ & $93.6 \mathrm{Mn}$ \\
\hline & $\mathrm{CV}$ & 163.67 & 346.61 & 313.01 & 238.90 & 196.84 & 79.76 & 260.64 & 2022.09 & -1715.50 & 273.75 \\
\hline \multirow{2}{*}{$\begin{array}{l}\text { Model } \\
\text { 2b }\end{array}$} & $\begin{array}{l}\text { Median } \\
\text { NPV }\end{array}$ & $99.3 \mathrm{Mn}$ & $99.9 \mathrm{Mn}$ & $112.0 \mathrm{Mn}$ & $112.9 \mathrm{Mn}$ & $113.6 \mathrm{Mn}$ & $112.9 \mathrm{Mn}$ & $87.0 \mathrm{Mn}$ & 87.7 Mn & $99.2 \mathrm{Mn}$ & $99.7 \mathrm{Mn}$ \\
\hline & $\mathrm{CV}$ & 153.99 & 315.19 & 312.43 & 226.38 & 179.26 & 71.42 & 265.17 & 2193.96 & -956.07 & 261.79 \\
\hline \multirow{2}{*}{$\begin{array}{c}\text { Model } \\
\text { 3b }\end{array}$} & $\begin{array}{l}\text { Median } \\
\text { NPV }\end{array}$ & $83.1 \mathrm{Mn}$ & $83.8 \mathrm{Mn}$ & $85.4 \mathrm{Mn}$ & $86.4 \mathrm{Mn}$ & $85.8 \mathrm{Mn}$ & $85.5 \mathrm{Mn}$ & $80.3 \mathrm{Mn}$ & $80.6 \mathrm{Mn}$ & $82.3 \mathrm{Mn}$ & $82.4 \mathrm{Mn}$ \\
\hline & $\mathrm{CV}$ & 172.20 & 386.09 & 313.23 & 246.16 & 207.85 & 89.49 & 283.09 & 2906.14 & -758.31 & 267.78 \\
\hline \multirow{2}{*}{$\begin{array}{l}\text { Model } \\
4 b\end{array}$} & $\begin{array}{l}\text { Median } \\
\text { NPV }\end{array}$ & $78.7 \mathrm{Mn}$ & $79.3 \mathrm{Mn}$ & $77.9 \mathrm{Mn}$ & $78.9 \mathrm{Mn}$ & $78.7 \mathrm{Mn}$ & $78.6 \mathrm{Mn}$ & $78.9 \mathrm{Mn}$ & $79.3 \mathrm{Mn}$ & $80.2 \mathrm{Mn}$ & $80.1 \mathrm{Mn}$ \\
\hline & $\mathrm{CV}$ & 178.08 & 411.91 & 0.00 & 0.00 & 218.00 & 96.64 & 287.98 & 3163.74 & -717.14 & 269.48 \\
\hline
\end{tabular}

Figure 2: Scenario B (LH), Comparison of Median NPV of unhedged and hedged models vs. no-currency fluctuations

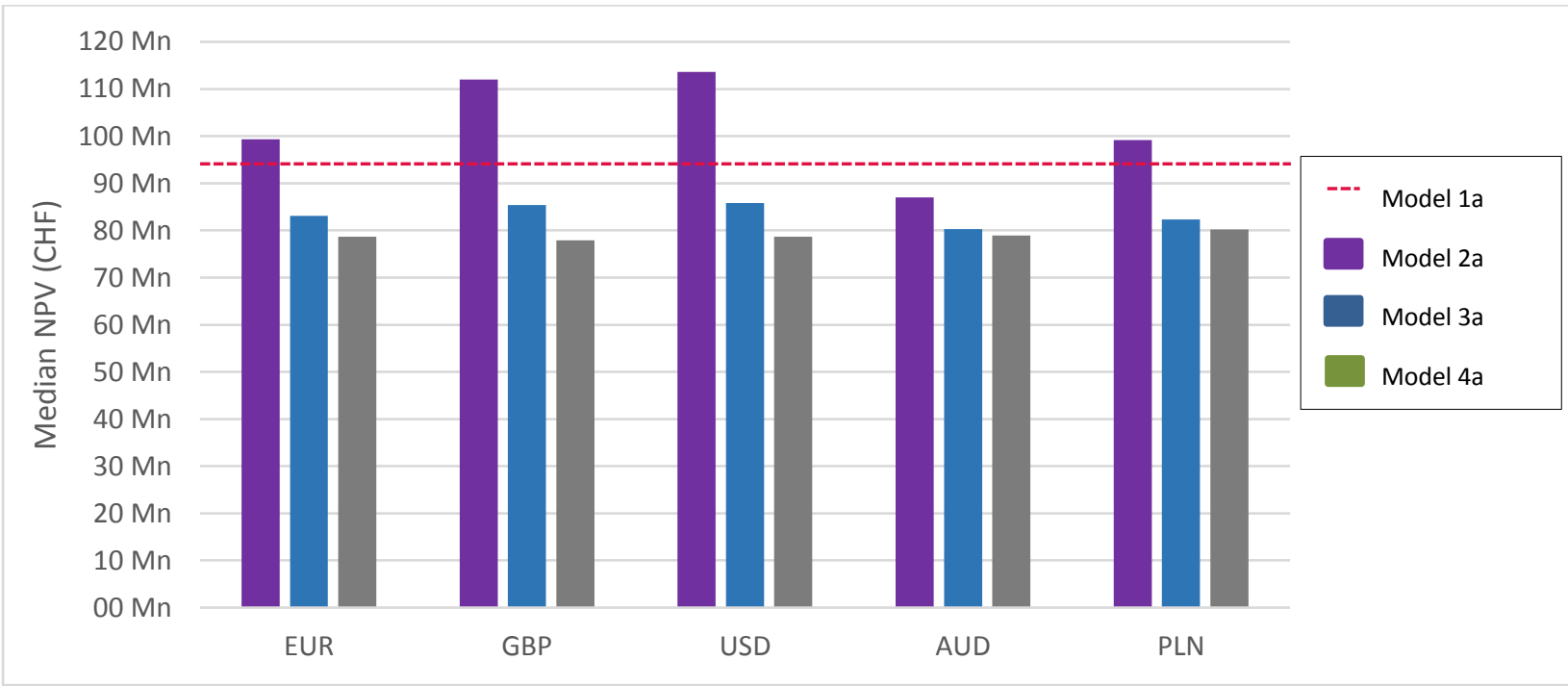

According to the results in scenario B (Table 4), returns for a domestic investor (model $1 \mathrm{~b}$ ) were outperformed when exposure to the EUR, GBP, USD and PLN was incorporated (model $2 b$ ). Taking into account the outcomes of scenario $A$ as well as the exchange rates in the reverse scenario, higher median NPVs and lower CVs are no surprise for model $2 b$. Hedging against currency movements, on the other hand, resulted in significantly lower returns and the highest risk for all currency pairs. Equivalent to the findings of scenario A, investors seem to benefit from currency movements when exposed to a historically appreciating currency against the home currency. Scenario B confirmed that using a currency swap to hedge a sideways fluctuating currency, like the AUD, would result in lower returns compared to a hedge-free strategy. The most successful hedging strategy for the reverse scenario was to hedge the initial purchase price and the rental income (model 3b). Considering that in scenario 
$B$ the initial cap rate was 1.05ppts higher than the mean exit cap rate, the results are in line with the conclusions drawn from scenario A, confirming that a large gap between initial cap rate and historical mean leads to higher returns when the initial purchase price is hedged.

When only the exchange rates of the different currency pairs are analysed, there is no evident difference identifiable between the developed markets and the comparatively less developed one (Poland). However, the CHF/PLN conversion rate showed the highest volatility amongst all currencies; hence, the highest swap costs were allocated to this exchange rate. The different movements of the pairs, especially in terms of timing, suggest that markets are not strongly converging.

The aim of this work was also to compare the two sampling methods used in the simulations. Overall, the divergence of both sampling methods is insignificant from a return perspective since median NPVs in both methods differ on average less than $1 \%$. This could be a result of the considerably large number of iterations used in the simulations, which leads to shorter intervals between the stratifications in LH sampling, whereby a convergence of both $\mathrm{LH}$ and MC methods can be observed. Hence, the advantage of LH over MC of being able to produce reliable results with fewer iterations decreases with the number of samples, where the median effectively approaches almost equilibrium, as seen in the results of this study. In contrast, there is a substantial deviation between both sampling methods from a risk perspective - i.e. $\mathrm{CV}$. This has been observed in both components of CV, the mean NPV as well as SD, meaning that despite the large number of iterations, the dispersion of these stochastic values in MC sampling does not converge to the samples created with LH. Although LH and MC sampling are sophisticated simulation tools, the results depend on the assumptions incorporated into the models.

\section{Discussion}

The outcome of the analysis of 5 currency pairs in this study indicated that hedging against exchange rate movements with currency swaps can only create higher returns in a specific framework. On one hand, a clear historically appreciation trend of an investor's home currency against the foreign one would favour a hedging strategy. In contrast, the exposure to the foreign exchange rate would add further returns to a property investment in the setting of a historically depreciating domestic currency. Considering the nature of a currency swap, which favours the counterparty who locked into the depreciating foreign currency, the results of both cases were expected.

The optimal strategy for sideways fluctuating currency movements is more difficult to predict, as encountered in the case of the CHF/AUD exchange rate. Scenario A and B of the Sydney investment resulted in higher NPVs when no currency hedge was employed. Figure 1 shows the range of impact of each input component of scenario A for the Sydney asset. For example, the rental growth rate in model $2 a$ can either reduce the mean NPV by $41.6 \mathrm{Mn}$, or increase it by $55.3 \mathrm{Mn}$, depending on the rental market development. The rental growth rate and exit cap rate (ECR) have nearly the same influence on NPV in all models of scenario $A$. The spread for the exchange rate (ER) at the end of the holding period is considerably higher for the unhedged model (2a) compared to hedging (i.e. model 3a \& 4a). Moreover, by being skewed to a positive impact, the quarterly ER change triggers further gains for a Swiss investor not hedging a commercial property investment in Sydney. This means that even though there is no clear identifiable trend in the CHF/AUD exchange rate, exposure to the Australian currency results in increased upward-risk with limited additional downward risk induced by the quarterly exchange rate change. 
Figure 3: Scenario A, Sydney, Model 2a \& 3a - Range of impact of inputs on output mean NPV

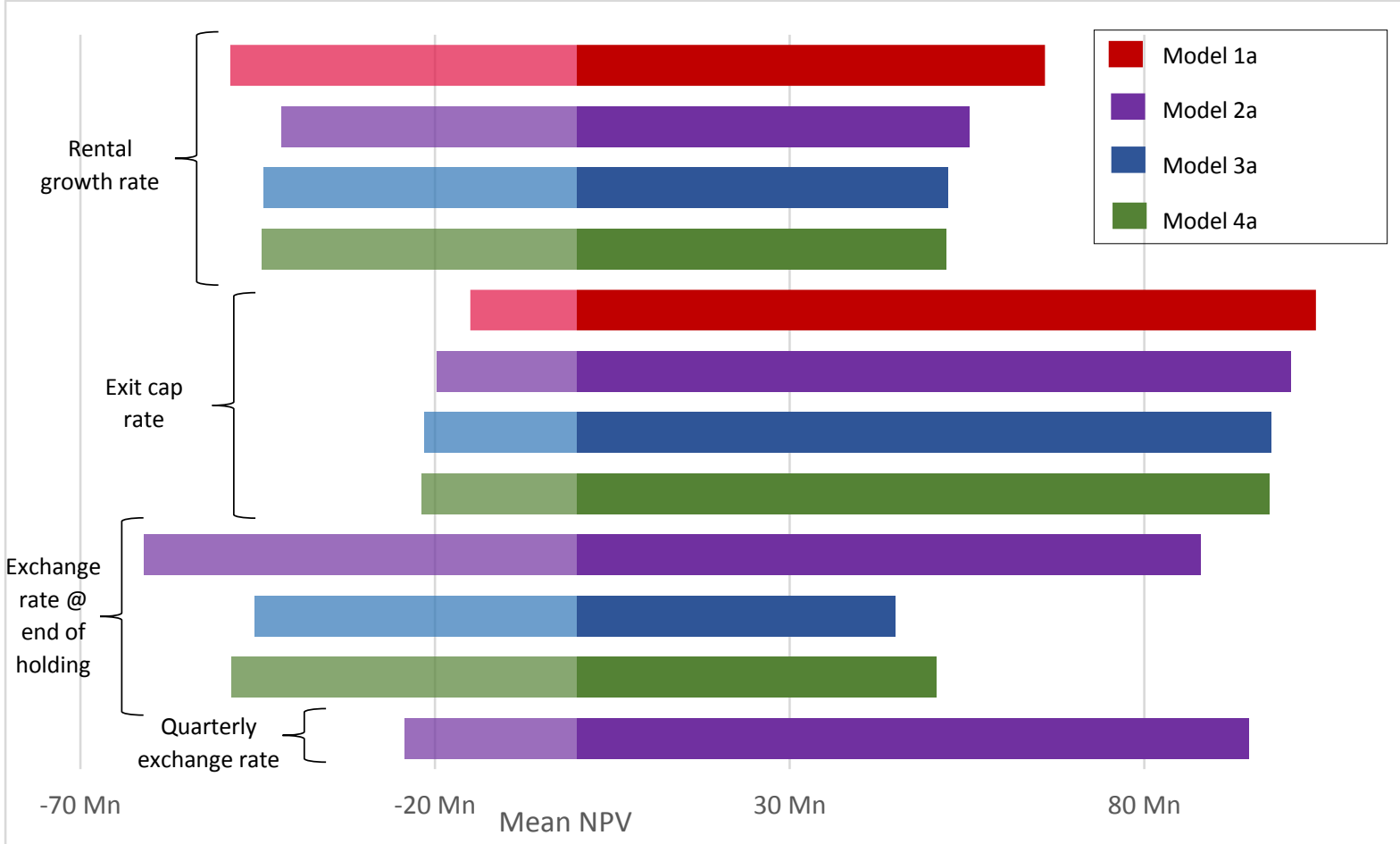

By enlarging the scope of the study undertaken by Johnson et al. (2005) with a broader spectrum of currencies with different historical fluctuations, the conclusion constructed by Johnson et al. that a currency swap reduces the down-side risk in general could not be fully confirmed. The results of the current study suggest that the performance of a hedging strategy essentially depends on the framework of the specific currency. Except for the Australian case, the currency movements in scenario $A$ would favour a hedging strategy from a return perspective as well as from a risk perspective due to the appreciation of the CHF. Conversely, Scenario B suggested that an investor may benefit from exposure to the appreciating Swiss Franc, thus favouring a no-hedge strategy. Another consideration, however, is the possibility of more extreme, unpredictable shocks, such as the GFC or the abolishment of a fixed exchange rate. In these situations, a hedging strategy with currency swaps could reduce the risk from severe adverse currency movements, protecting the investor from these unforeseen situations. Figure 2 shows the quarterly mean exchange rates of the studied currencies to the CHF over a 5-year period beginning just prior to the start of the GFC (Q1 2007 - Q4 2011). During this time the Swiss Franc gained in value against all examined currencies. Within 2 years, the GBP depreciated against the CHF by $24.5 \%$, while the AUD lost $19.8 \%$ in value by the end of 2008. This would mean a constant loss for a Swiss investor holding regular incomeproducing properties in these markets. It could be argued that in such extreme cases, the investor would cease to repatriate the quarterly proceeds until a more favourable exchange rate applies; however, in case the cash flow would need to be repatriated in the course of the holding period, adverse currency movements would diminish the gains from the real estate investment. If a 5-year holding period is assumed, as set in this study, an investor would have seen $40.5 \%$ depreciation of the GBP at the end of the holding period of a property acquired at the beginning of 2007 . Assuming a $107,639 \mathrm{ft}^{2}$ core London office property with a rent of GBP $102.5 / \mathrm{ft}^{2}$ p.a. and an initial cap rate of $5.15 \%$ as well as an ECR in 2011 of $5.77 \%$, a Swiss investor would suffer from a negative NPV if all proceeds are repatriated on a quarterly basis without hedging (Table 5). Compared to a domestic investor, however, these losses could be 
minimized through the application of a currency swap. In an ex-post framework, the TV of the property should be hedged, since locking into the initial purchase price would result in overhedging due to the increasing cap rate. By hedging the TV, the spread of NPVs between the Swiss and the domestic investor would be GBP $3 \mathrm{Mn}$, or $21 \%$, which is significantly lower compared to the unhedged scenario (spread of GBP $86 \mathrm{Mn}$; see Table 5). A similar outcome applies to a real estate investment during the same time frame in Sydney, where rents of AUD $807 / \mathrm{m}^{2}, 7.07 \%$ initial cap rate and $7.48 \%$ ECR have been assumed on $10,000 \mathrm{~m}^{2}$ (Table 5). A domestic market actor would see 35\% higher returns compared to a no-hedge strategy, yet in contrast, only $6 \%$ higher NPVs vis-à-vis a currency swap where the terminal value is locked in.

After the abolishment of the fixed exchange rate with the EUR in Q4 2014, a similar outcome to the above mentioned would be expected, considering that the CHF appreciated $12.2 \%$ against the AUD and 9\% against the EUR within 2 years. However, since one of the major issues in currency swaps with underlying real estate investments is finding a suitable counterpart, the dependency for Swiss investors to engage in swaps in order to secure a satisfactory return potentially negatively impacts their capacity for international property investments.

Figure 4: Exchange rates to CHF Q1/2007 - Q4/2011; Source: Authors' own, based on SNB (2016)

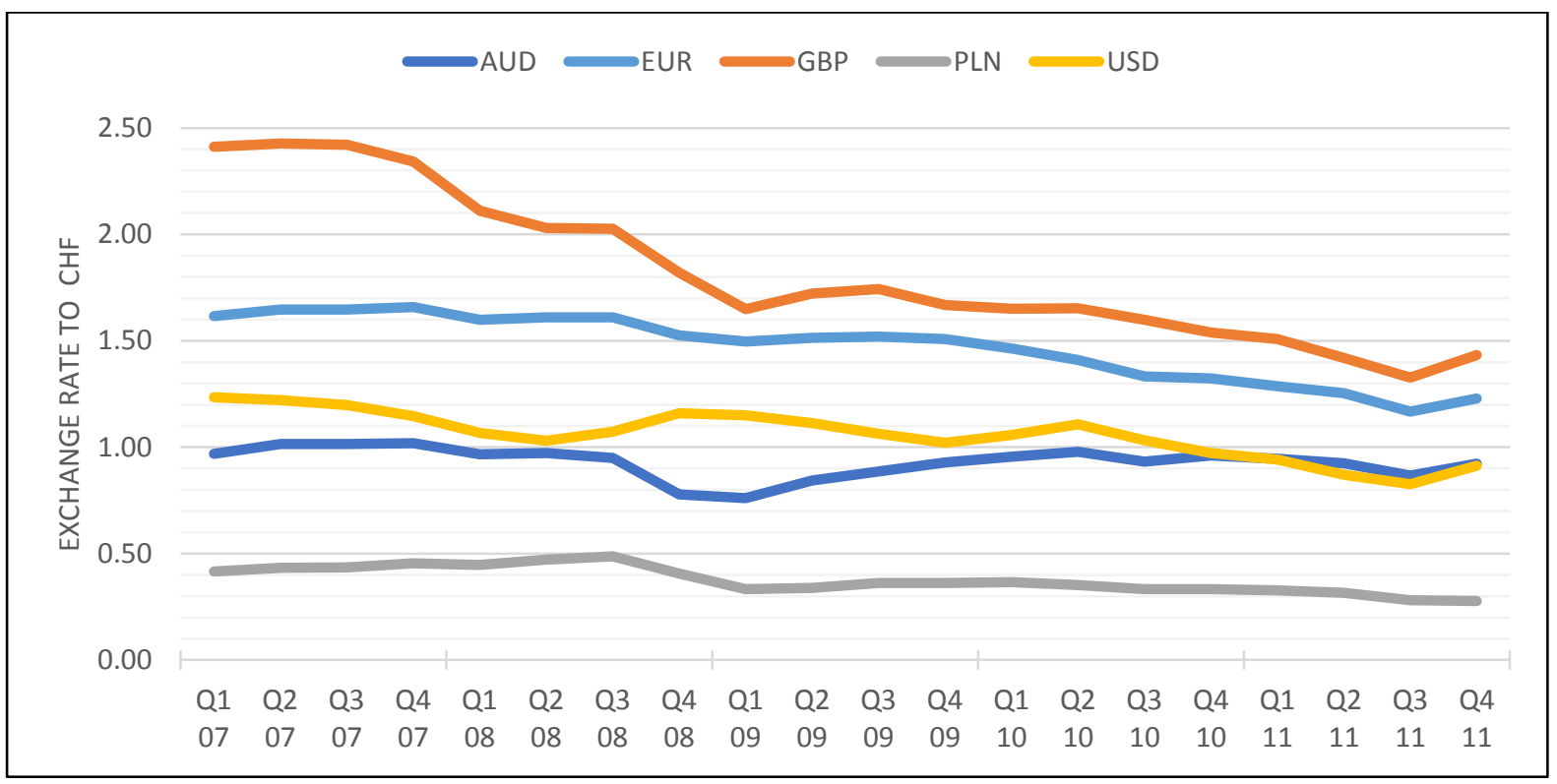

Table 5: Details of ex-post analysis Q1/2007 - Q4/2011

\begin{tabular}{|l|c|c|}
\cline { 2 - 3 } \multicolumn{1}{c|}{} & GBP & AUD \\
\hline Size & 107,639 sqft & 10,000 sqm \\
\hline Rent & AUD $25.63 \mathrm{psqm}$ & AUD $201.75 /$ sqm \\
\hline Initial cap rate & $5.15 \%$ & $7.07 \%$ \\
\hline Exit cap rate & $5.77 \%$ & $7.48 \%$ \\
\hline
\end{tabular}




\begin{tabular}{|l|l|l|} 
& Model 1:16.84 Mn & Model 1: 24.73 Mn \\
NPV in CHF & Model 2: $-69.15 \mathrm{Mn}$ & Model 2: 18.17 Mn \\
& Model 4: 13.23 Mn & Model 4: 23.24 Mn \\
\hline
\end{tabular}

\section{Conclusions}

In light of the recent instability in the political and economic environment, which caused considerable volatility on the global financial markets, this paper resumes the discussion on the efficacy of currency swaps for real estate investments. The upwards adjustment of the Swiss Franc following the abolishment of the fixed exchange rate against the Euro was used as the basis of discussion. By adopting the view of a risk-averse, small-scale investor, who seeks to gain exposure to foreign direct real estate investment, the effectiveness of a currency swap to hedge against adverse exchange rate movements with exposure to the AUD, EUR, GBP, PLN, USD and CHF, respectively, was investigated. By using stochastic sampling techniques, namely Monte Carlo and Latin Hypercube sampling, a forward-looking expectations framework was created. The median NPVs created with LH and MC were nearly identical. Presumably, the large number of iterations resulted in smaller intervals between individual stratifications, where median values created with $\mathrm{LH}$ effectively approached equilibrium with the samples of MC. This was not observed for the mean NPVs and standard deviations, meaning that despite the large number of iterations, the dispersion of the stochastic values in MC sampling does not converge to the samples created with $\mathrm{LH}$.

The results indicate that the efficacy of a currency swap depends on the historical framework of the exchange rates. If the foreign currency depreciates against the domestic one, hedging the quarterly repatriated cash-flow of a real estate investment proved to be superior to the unhedged strategy. On the other hand, an investor would benefit from exposure to a historically appreciating foreign currency and could even achieve higher returns compared to the domestic market player, with an unhedged strategy clearly outperforming the currency swap. A historically sideways fluctuating exchange rate, like the AUD to the CHF, would also favour an unhedged approach. However, unexpected shocks such as the GFC or the abolishment of a fixed exchange rate, with significant effects on the exchange rates during the assumed holding period of a property, could cause negative consequences on the repatriated proceeds. By locking into a fixed conversion, the potential damage of such 'black swan events' can be obviated through currency swaps, making them a useful vehicle for risk-averse investors in an unstable political-economic environment. The specific hedging strategy with currency swaps is dependent on the current property market situation. The anticipated terminal value and the quarterly repatriated rental income should be hedged when the market cap rates are fluctuating close to the historical mean. Conversely, the preferable strategy in a situation of strongly divergent cap rates from the historical mean would be to lock into the purchase price and the quarterly rental income.

Research limitations/implications: As the research considers hedged versus unhedged scenarios it excludes transfer and operational taxes, and does not consider tax-optimising structures. The impact of taxes could be developed in detail through further research, including different types of transactions, while expanding the study into additional markets and examining further currency pairs. Furthermore, the impact of currency swaps used in single assets on a portfolio level could be subject for further investigations.

\section{Notes}

1. 'Pseudo' recognises that even sophisticated simulation software can only mimic randomness (Brandimarte, 2014; Barreto \& Howland, 2006). 
2. At the time of writing the exchange rates adopted for the $\mathrm{CHF}$ in relation to the other five currencies were as follows:

CHF/GBP: 0.7179

CHF/EUR: 0.9122

CHF/PLN: 3.9872

CHF/AUD: 1.3813

CHF/USD: 1.0305

\section{References}

Amedee-Manesme, C., Barthelemy, F., Baroni, M. and Dupuy, E. (2013) 'Combining Monte Carlo simulations and options to manage the risk of real estate portfolios', Journal of Property Investment \& Finance, 31 (4), pp. 360-389.

Barras, R. (2009) 'Building Cycles: Growth and Instability’, Wiley Blackwell; Oxford.

Barreto, H. and Howland, F. (2006) 'Introductory Econometrics - Using Monte Carlo Simulation with Microsoft Excel', Cambridge: Cambridge University Press.

Baum, A. (1995) 'Can Foreign Real Estate Investment Be Successful?' Real Estate Finance, $12(1)$, pp. 81-89.

Baum, A. and Hartzell, D. (2012) 'Global Property Investment - Strategies, Structures, Decisions', Chichester: Wiley - Blackwell.

Brandimarte, P. (2014) Handbook in Monte Carlo Simulation: 'Applications in Financial Engineering, Risk Management, and Economics', Hoboken: John Wiley \& Sons.

Brooks, C. and Tsolacos, S. (2010) 'Real Estate Modelling and Forecasting', Cambridge University Press: Cambridge.

Brown, R. J. (2004) 'Risk and Private Real Estate Investments', Journal of Real Estate Portfolio Management, 10 (2), pp. 113-127.

Cheung Y., Chinn M. and Pascual A. (2005) 'Empirical Exchange Rate Models of the Nineties: Are any fit to survive?', Journal of International Money Finance, 24, pp. 1150-1175.

Costello, J. (2016) 'Who is making the market?' RCA Insights, $14^{\text {th }}$ October 2016, available at: https://www.rcanalytics.com/who-is-making-the-market/ Accessed 01.06.2017

Dales, A. and Meese, R. (2001) 'Strategic currency hedging', Journal of Asset Management, 2 (1), pp. 9-21.

Eichholtz, P. (1996) 'Does International Diversification Work Better or Real Estate than for Stocks and Bonds?' Financial Analysts Journal, 52 (1), pp. 56-62.

Eun, C. and Resnick, B. (1988) ‘Exchange Rate Uncertainty, Forward Contracts, and International Portfolio Selection'. The Journal of Finance, 43 (1), pp. 197-215.

Falkenbach, H. (2009) 'Market selection for international real estate investments', International Journal of Strategic Property Management, 13 (4), pp. 299-308.

Fuerst, F. \& Matysiak, G. (2013) 'Analysing the performance of nonlisted real estate funds: a panel data analysis', Applied Economics, 45 (14), pp. 1777-1788. 
Hoesli, M. \& Chaney, A. (2010) 'The interest rate sensitivity of real estate', Journal of Property Research, 27 (1), pp. 61-85.

Hoesli, M., Jani, E., \& Bender, A. (2006) 'Monte Carlo simulations for real estate valuation', Journal of Property Investment \& Finance, 24 (2), pp. 102-122.

Hoesli, M., Lekander, J. and Witkiewicz, W. (2004) 'International Evidence on Real Estate as a Portfolio Diversifier', Journal of Real Estate Research, 26 (2), pp. 161 - 206.

Hoesli, M. \& MacGregor, B. D. (2000) 'Property Investment: Principles and Practice of Portfolio Management', Pearson Education Limited, Essex.

Hoesli, M. \& Reka, K. (2013) 'Volatility Spillovers, Comovement and Contagion in Securitized Real Estate Markets'. The Journal of Real Estate Economics and Finance, 47 (1), pp. 1-35.

James, J., Marsch, I. and Sarno, L. (2012) 'Handbook of Exchange Rates'. John Wiley \& Sons; New Jersey.

Johnson, R., Lizieri, C., Soenen, L. and Worzala, E. (2005) 'Hedging Private International Real Estate', available at: http://centaur.reading.ac.uk/20946/ Accessed on 27.04.2015

Johnson, R., Lizieri, C., Soenen, L., \& Worzala, E. (2006): 'Simulating Currency Risk on Private Investments in Real Estate', Journal of Real Estate Portfolio Management, pp. 91101.

Johnson, R., Worzala, E., Lizieri, C. \& Kinnard, W. (2001) 'Mitigating Currency Risk for International Hotel Investments: Can it be done?' Real Estate Finance, 18 (2), pp. 62-72.

Keogh, G. \& D'Arcy, E. (1994) 'Market maturity and property market behaviour: A European comparison of mature and emergent markets'. Journal of Property Research, 11 (3), pp.215-235.

Lang, S. \& Scholz, A. (2015) 'The diverging role of the systematic risk factors: evidence from real estate stock markets'. Journal of Property Investment \& Finance, 33 (1), pp.81-106.

Lizieri, C., and Finlay, L. (1995): 'International property portfolio strategies', Journal of Property Valuation and Investment, 13 (1), pp. 6-21.

Loh, W. (1996) 'On Latin Hypercube Sampling'. The Annals of Statistics, 24 (5), pp. 20582080.

Matsumoto, M. and Nishimura, T. (1998) 'Mersenne Twister: A 623-Dimensionally Equidistributed Uniform Pseudo-Random Number Generator', ACM Transactions on Modelling and Computer Simulation, 8 (1), pp. 3-30.

Mark, N. (1995) 'Exchange Rates and Fundamentals - Evidence on Long-Horizon Predictability', American Economic Review, 85, pp. 201-218.

Markowitz, H. (1952) ‘Portfolio Selection’. The Journal of Finance, 7 (1), pp. 77-91.

McKay, M., Beckmann, R. and Conover, W. (1979) 'Comparison of Three Methods for Selecting Values of Input Variables in the Analysis of Output from a Computer Code', Technometrics, 21 (2), pp. 239-245. 
Moss, A., Clare, A., Thomas, S. \& Seaton, J. (2015) 'Trend following and momentum strategies for global reits'. Journal of Real Estate Portfolio Management, 21 (1), pp. 21-31.

Newell, G. \& Webb, J. (1996) 'Assessing Risk for International Real Estate Investments'. Journal of Real Estate Research, 11 (2), pp.103 - 115.

Odier, P. and Solnik, B. (1993) 'Lessons for International Asset al.location', Financial Analysts Journal, 49 (2), pp. 63-77.

Pfnür, A. \& Armonat, S. (2013) 'Modelling uncertain operational cash flows of real estate investments using simulations of stochastic processes', Journal of Property Investment \& Finance, Vol. 31 (5), pp.481 - 501.

PIA (2016) ‘Property Data Report 2016’. PIA, London.

Rossi, B. (2013) ‘Exchange Rate Predictability', Journal of Economic Literature, 51 (4), pp. 1063-1119.

Sayce, S., Smith, J., Cooper, R. and Venmore-Rowland, P. (2006) 'Real Estate Appraisal: From Value to Worth', Oxford: Blackwell Publishing.

Sirmans, C. and Worzala E. (2003) 'International Direct Real Estate Investment: A Review of the Literature', Urban Studies, 40 (5-6), pp. 1081-1114.

Soenen, L. and Lindvall, J. (1992) 'Benefits from diversification and currency hedging of international equity investments: different countries' viewpoints', Global Finance Journal, 3 (2), pp. 145-158.

Sokolowski, J. (2010) 'Monte Carlo Simulation', in: Sokolowski, J. and Banks, C., 'Modelling and Simulation Fundamentals: Theoretical Underpinnings and Practical Domains', Hoboken, USA: John Wiley \& Sons, pp. 131-145.

Srivatsa, R. \& Lee, S. L (2012) 'European real estate market convergence'. Journal of Property Investment \& Finance, 30 (5), pp. 458-472.

Steinberg, D. and Lin, D. (2006) 'A construction method for orthogonal Latin hypercube designs', Biometrika, 93 (2), pp. 279-288.

Stevenson, S. (2000) 'International Real Estate Diversification: Empirical Tests using Hedged Indices'. The Journal of Real Estate Research, 19 (1/2), pp.105 - 131.

SNB (2015) 'Swiss National Bank discontinues minimum exchange rate and lowers interest rate to $-0.75 \%$ ', Press Release, SNB, 15.01.2015. Available at:

http://www.snb.ch/en/mmr/reference/pre 20150115/source/pre 20150115.en.pdf Last accessed: 25.11.2016

Wilson, P. J. \& Zurbruegg (2003) 'International Diversification of Real Estate Assets: Is It Worth It? Evidence from the Literature'. Journal of Real Estate Literature, 11 (3), pp. 259 277.

Worzala, E. (1995) 'Currency risk and international property investments'. Journal of Property Valuation and Investment, 13 (5), pp. 23-38.

Worzala, E., Johnson, R. and Lizieri C. (1997) 'Currency swaps as a hedging technique for an international real estate investment', Journal of Property Finance, 8 (2), pp. 134-151. 
Ziobrowski, A. and Ziobrowski, B. (1993) 'Hedging Foreign Investments in U.S. Real Estate with Currency Options', The Journal of Real Estate Research, pp. 27-54

Ziobrowski, A., Ziobrowski, B. and Rosenberg, S. (1997) 'Currency Swaps and International Real Estate Investment', Real Estate Economics, 25 (2), pp. 223-251. 